Отримано: 13 березня 2018 р.

Прорецензовано: 15 березня 2018 р.

Прийнято до друку: 19 березня 2018 р.

e-mail: valerymykhaylenko@i.ua

DOI: $10.25264 / 2519-2558-2018-1(69) / 2-25-28$
Mykhaylenko Valery. Internationalisms in cross-cultural communication. Наукові записки Наиіонального університету «Острозька академія»: серія «Філологія». Острог : Видво НаУОА, 2018. Вип. 1(69), ч. 2, березень. С. 25-28.

\title{
Valery Mykhaylenko,
}

Institute of International Relations \& Social Studies. MAUP, Kyiv

\section{INTERNATIONALISMS IN CROSS-CULTURAL COMMUNICATION}

The present paper is a study of financial internationalisms in the scientific worldview of most European Languages. They are considered to be a factor integrating a professional world community, but they disintegrate the society into professionals and non-professionals. On the contrary, the conceptual system of the naïve worldview integrates the society. The corpus of financial terms has been retrieved from Romance, Germanic, Slavic, Baltic and one of Finnic (Finno-Ugric) languages to reveal the conceptual system represented by the dominant lexeme 'finance', which developed into an internationalism and the conceptual system represented by the dominant lexeme 'money', which did not develop into an internationalism. The both systems organize one common system, though they vary pragmatically. In our research we attempted to define (1) the role of financial internationalisms in disintegrating the societv; (2 the role of the financial naïve worldview in integrating the society, (3) the role of code switching the conceptual systems; and (4) the role of internationalisms in securing cross-cultural communication of the world expertise community.

Key words: internationalism, cross-cultural communication, discourse, conceptual system, semantic field.

Михайленко Валерій Васильович,

Інститут міжнародних відносин і соиіальних наук, МАУП, м. Київ

\section{ІНТЕРНАЦІОНАЛІЗМИ У МІЖКУЛЬТУРНІЙ КОМУНІКАЦІї}

Наша робота є дослідженням фінансових інтернаціоналізмів у науковій та наївній картинах світу більшості європейських мов. Ми вважаємо їх фактором інтеграції професійної світової спільноти, але в той же час вони дезінтегрують суспільство на професіоналів і не професіоналів. Проте, кониептуальна система, представлена не інтернаиионалізмом у наївній картині світу об'єднує суспільство. Корпус фінансових термінів був отриманий з романських, германських, слов 'янських, балтійських та одноі з фінно-угорських мов.

Ключові слова: інтернаціоналізм, картина світу, дискурс, міжкультурна комунікаџія, концептосфера, семантичне поле.

\section{Михайленко Валерий Васильевич,}

Институт междунарожных отношений и сочиальных наук, МАУП, г. Киев

\section{ИНТЕРНАЦИОНАЛИЗМЫ В МЕЖКУЛЬТУРНОЙ КОМУНИКАЦИИ}

Настоящая работа представляет собой исследование финансовых интернационализмов в научной и наивной картинах мира большинства европейских языков. Мы считаем их фактором интеграции мирового экспертного сообщества, но в тоже время они дезинтегрируют общество на профессионалов и не профессионалов. Напротив, концептуальная система, представленная не интернационализмом в наивной картине мира объединяет общество. Корпус финансовых терминов был получен из романских, германских, славянских, балтийских и одного из финно-угорских языков.

Ключевые слова: интернационализм, дискурс, картина мира, межкультурная коммуникация, кониептосфера, семантическое поле.

PREAMBLE. When a loan or borrowing is considered to be a means of increasing a lexicon by natural languages it is a consequence of a more universal cause - the necessity of exchange of artifacts and notions of material and spiritual culture [see: 24 , p.51; p.62]. According to Karlheinz Hengst an internationalism is a loanword spread across several languages with the phonetic and morphologic forms and a constant meaning [13, p.467, see also: 4, p. 191].

In this paper we address financial internationalisms or loanwords - and their use in the both types of worldview- scientific and naïve.

Assumption 1. The scientific worldview reflected in the professional discourse is a prerogative of a definite group of people sharing one profession and inside of the group a professional discourse is employed. James F. Schaeffer admits that the worldview is a set of presuppositions or assumptions held consciously or unconsciously, consistently or inconsistently, about the basic make up of reality" [21, p.355fl.].

Assumption 2. The role of the scientific worldview is to unite professional communities of different countries, we would specify - only a part of reality, i.e. a limited area by the special branch of science or craft with its definition, methodology, methods of analysis and terms. Science refers to a system of acquiring knowledge and uses observation and experimentation to describe and explain natural phenomena.

Assumption 3. The financial, in our case, internationalisms due to their expansion from the Donor language to the Receptor languages refer to the way of the, first, European [see: 5; 6], and, then Global language development.

THEORETICAL CONSIDERATIONS. We have searched in various encyclopedic, etymological, and bilingual dictionaries for loanwords representing a financial conceptual system functioning in a number of languages showing the same or nearly the same semantic, syntactic and lexical structure which can be labeled as internationalisms or Anglicisms in the scientific and naïve worldviews. Each language in the process of its historical development borrows many notions hitherto unknown in this language. Internationalisms are word-groups and even sentences which have been borrowed in the same or similar analogies lingual form and in 
the same meaning [2, p.231]. Internationalisms are acknowledged as such when they are used in, at least, three languages belonging to different language families (groups). "Genuine" internationalisms, are the words and word-groups (rarely sentences) maintaining in several languages the same or a similar phonetic and morphological form. The classification of loans or borrowings [12, p. 211] is based on various taxonomies suggested by many scholars [24, p.51; 10; p.62]. Manfred Gorlach makes a distinction between loanwords and aliens. The former relate to lexical items that are fully integrated into a language, the latter refer to words which, due to phonological and morphological differences with the receptor language or other factors, will not be successfully integrated. The borrowings which come from English are labeled 'Anglicisms' -- "words or idioms" that are recognizably English in their form but are accepted as items in the Receptor language [2, p.231; 9; 10, p.1;]. Sometimes Anglicisms are used in everyday life as trendy slang which lends an exotic feel to the language; they also refer to concepts otherwise lacking in the Receptor languages. The ease of and preference for using Anglicisms lie sometimes in their condensing of otherwise long paraphrases, such as the use of start-up, upgrade, hamburger, etc., which may be translated with the help phrases in the Receptor languages. The role of English in transmitting many internationalisms is evident in many cases.

RESEARCH METHODOLOGY, CORPORA AND DICTIONARIES. The analyses presented in this paper rest on two complementary theoretical approaches: internationalisms [see also "Anglicisms": 2, p. 231] in the framework of Global English and corpus linguistics, both relatively recent developments in language study [Pulcini et al., 2012, p.5-6]. It should be noted, though, that Romance (Latin-based) element, which is quite strong in the technical, scientific and academic vocabulary of English is also conducive to forms of interlinguistic contact represented by internationalisms easily integrated in the morphological and phonological systems of these languages.

The conceptual system «finance» is represented by the dominant lexeme finance which originates in c. 1400, «an end, settlement, retribution,» from Old French finance «end, ending; pardon, remission; payment, expense; settlement of a debt» (13c.), noun of action from finer «to end, settle a dispute or debt,» from fin (see fine (n.)), cf.: Medieval Latin finis «a payment in settlement, fine or tax.» The notion is of «ending» (by satisfying) something that is due (compare Greek telos «end;» plural tele «services due, dues exacted by the state, financial means»). The French components gradually were brought into English: «ransom» (mid-15c.), «taxation» (late 15c.); the sense of «management of money, science of monetary business» first recorded in English 1770 (Etymology Dictionary). The conceptual system of finance can organize all the nouns sharing the common component finance into a semantic field and further subclassify them into four subfields actualizing the corresponding four subsystems. Accordingly, in professional discourse the conceptual system of finance is represented by the semantic field finance with its four micro-fields. The concepts budget, capital, fund, bank, default, deficit, bank, credit, invest, interest representing the core of the Finance wordstock do not belong to the native vocabulary, they were borrowed mostly from Latin mostly through French for instance: The noun lexeme budget has been used since early 15c., bouget, «leather pouch, small bag or sack,»adapted from Middle French bougette, diminutive of Old French bouge «leather bag, wallet, pouch,»which came from Latin bulga «leather bag,» a word of Gaulish origin (compare Old Irish bolg «bag,» Breton bolc'h «flax pod»), see the root: PIE *bhelgh- «to swell,» extended form of root *bhel- «to blow, swell» (Etymological Dictionary). So an indirect borrowing from Latin through French started a new life in the English financial system: the modern financial meaning «statement of probable expenditures and revenues» (1733) is from the notion of the treasury minister keeping his fiscal plans in a wallet.

The adjectival lexeme capital began to function in early 13c., «of or pertaining to the head,» from Old French capital, originally it came from Latin capitalis «of the head,» hence «capital, chief, first,» from caput (genitive capitis) «head» It has been used since Meaning «main, principal, chief, dominant, first in importance» is from early 15c. in English. See: PIE root *kaput- «head». 1610s, «a person's wealth,» from Medieval Latin capitale «stock, property,» noun use of neuter of Latin capitalis «capital, chief, first» (see capital (adj.)). The noun term capital made its first appearance in medieval Latin as an adjective capitalis to designate the principal sum of a money loan, which was contrasted with the «usury»-- later called interest--the payment made to the lender in addition to the return of the sum lent. This usage was not recorded in classical Latin and became common by 13c. and possibly had begun as early as 1100 A.D., in the first chartered towns of Europe. Meaning «stock of money or wealth available for some purpose» is from 1690s; sense of «store of anything to be drawn upon» is from 1704. Funds «money at one's disposal» is from 1728 (Etymological Dictionary).

The lexeme bank in the meaning of «financial institution,» late 15c., originally it meant «money-dealer's counter or shop,» from either Old Italian banca or Middle French banque (itself from the Italian word), both meaning «table,» from a Germanic source (such as Old High German bank «bench, moneylender's table»). See the root: Proto-Germanic *bankiz-»shelf,» *bankon- ) (Etymological Dictionary). The etymological notion is of the moneylender's exchange table. It has been in use as «institution for receiving and lending money» since 1620 s.

The noun lexeme credit has been known since $1520 \mathrm{~s}$, borrowed from Middle French crédit (15c.) «belief, trust,» or from Italian credito developed from Latin creditum «a loan, thing entrusted to another,» from past participle of credere «to trust, entrust, believe» (Etymological Dictionary). The commercial sense was the original one in English (creditor is mid-15c.).

The noun lexeme default originates from early 13c., «offense, crime, sin,» later (late 13c.) «failure, failure to act,» came from Old French defaute (12c.) «fault, defect, failure, culpability, lack, privation,» which in its turn came from Vulgar Latin *defallita «a deficiency or failure,» past participle of *defallereßLatin de- «away»+ fallere «to deceive, to cheat; to put wrong, to lead astray, cause to be mistaken; to escape notice of, be concealed from». The financial sense is first recorded 1858 (Etymological Dictionary).

The noun lexeme deficit registered in English in 1782, developed from French déficit (late 17c.), originates from Latin deficit «it is wanting,» an introductory word in clauses of inventory, third person singular present indicative of deficere «to be deficient»(Etymological Dictionary)

Lt's take the noun lexeme interest representing a general conceptual system of finance, which also actualizes financial relations of legal entities and individuals through banking. It originates from mid-15c., «legal claim or right; a concern; a benefit, advantage" from Old French interest «damage, loss, harm» (Modern French intérêt), from the noun use of Latin interest «it is of importance, it makes a difference,» 3-rd person Sg. Present of interresse «to concern, make a difference, be of importance,» literally «to be between,» from inter» between» ( + esse «to be» (from PIE root *es- «to be»). The sense development to «profit, advantage» in French 
and English is not entirely clear. The earlier Middle English word was interesse (late 14c.), from Anglo-French interesse «what one has a legal concern in,» from Medieval Latin interesse «compensation for loss,» noun use of Latin interresse (cf.: German Interesse, from the same Medieval Latin source) (Etymological Dictionary). The Financial component of «money paid for the use of money lent» (1520s) earlier was distinguished from usury (illegal under Church law) by being in reference to «compensation due from a defaulting debtor.» The component of «personal or selfish consideration» is from 1620s. The component of «business in which several people are interested» is from 1670s. The component of «curiosity, feeling that something concerns one, appreciative or sympathetic regard» is first attested 1771. In the discourse of economics reflecting the scientific worldview of the expertise community, it is defined in a variety of ways, for instance, "the payment of the use of service of capital or the payment made by borrower for the use of a loan, or the remuneration for mere abstinences." Compare the definition given by Investopedia: "Interest is the charge for the privilege of borrowing money, typically expressed as annual percentage rate (APR). Interest can also refer to the amount of ownership a stockholder has in a company, usually expressed as a percentage." We can verify this thesis with the help of the contrastivesemantic analysis of the lexeme finance in a number of languages: Fr. finance, Ital. finanza, Sp. financier, Prtl. financa, Rum. finanta, Ger. Finanzen, Afr. finansies, Dutch financien, Fris. finansjes, Dan. finansiere, Sw. finansiera, Nrw. finansiera, Check. finance, Slk. finance, Slvn. finance, Croat. financije, Lith. finansuoti, Let. finanses, Alb. finance, Bolg. фінанси, Ukr. фінанси, Rus. финансы, Bel. фінансы. In comparison with the expansion of the lexeme finance, which is registered by us in 17 languages of genealogically related and non-related groups, the use of the lexeme interest is somewhat limited: as an internationalism it is registered in 12 languages - Fr. interet, Germ. Interesse, Dut. interesseren, Dan. interesse, Sw. intressera, Nrw. interesse, rinter, Spanish interesar, Rom. interes, It. interesse, Prtl. interesse, Lexembourgh intressee, Let. interese; and 11 languages did not borrow that internationalism Afr. belangstelling, Frs.ian rinte (Ynteresse), Icelandic ahuga, Rus. процент, Ukr. відсоток, Belr. працэнт, Check zajem, Bulg. лихва, Pl. zainteresowanie, Estn. huvi, and Slk. vyhoda, zaujem.

Accordingly, globalization is not a phenomenon of XX-c., we believe it might have started when Medieval Latin finis was borrowed into Old French finance and later in the Norman-French form was brought into the England of XIII c. which adapted it in the form of finaunce. The Latin roots form the basis of the major part of the Financial Vocabulary of most modern languages Thus, here is a chain of borrowing sources: Medieval Latinà Norman French or Italian àMiddle Englissà Modern English, where Latin is the primary source, French and Italian are the transitional sources and English seems to be the most proliferating transitional source which can be a marker of globalizing [14, p.247fl.], first, finance communities and, second, the world beyond. In lexicology and lexicography such words are marked as borrowings [1, p.107-126] and sociolinguistics -- internationalisms. The given conceptual system singles out the finance expert community in the society and at the same time it unites such expertise communities across the countries.

The worldview includes the components of the conceptual worldview and is the only means of access to the national conceptual system. Linguists define the linguistic worldview as "naïve": the language structures the world, gives the net concepts to it and creates what is called the naïve worldview [23]. In the naïve worldview actualized by the non-professional discourse the lexeme money representing the financial conceptual system used by non-professional organizes all the noun lexemes sharing the common component money.

The lexeme money comes into English in mid-13c., denoting «coinage, metal currency,» from Old French monoie «money, coin, currency; change» (Modern French monnaie) which in its turn was borrowed from Latin moneta «place for coining money, mint; coined money, money, coinage,» from Moneta, a title or surname of the Roman goddess Juno, in or near whose temple money was coined; perhaps from monere «advise, warn». The lexeme money follows nearly the same phases of borrowing: Latinà Old French Middle English à Modern English, but did not become Again we shall turn to the definitional analysis of the lexeme money registered in the encyclopedic dictionary entries - (a) Cambridge: coins or notes (= special pieces of paper) that are used to buy things, or an amount of these that a person has. (b) Collins: (1) money is the coins or bank notes that you use to buy things, or the sum that you have in a bank account; (2) the official currency, in the form of banknotes, coins, etc, issued by a government or other authority; (3) particular denomination or form of currency; (4)property or assets with reference to their realizable value; (5) pecuniary sum or income (6) an unspecified amount of paper currency or coins.

(c) Merriam-Webster: something generally accepted as a medium of exchange, a measure of value, or a means of payment: (1.1.) officially coined or stamped metal currency; (1.2) newly minted money;(1.3) money of account (1.4.) paper money;(2.1.) handed the bank teller a wad of money;(2.2.) wealth reckoned in terms of money; (2.3.) made her money in the insurance business; (2.4.) an amount of money; (2.5.) raised the money;(2.6.) moneys or monies plural : sums of money --funds; (2.7.) the collection of tax monies;(3.1.) a form or denomination of coin or paper money; (4.1.) prize money ; (5.1.) persons or interests possessing or controlling great wealth; (5.2.) a position of wealth.

The naïve worldview unites the society, for instance, all age groups and all socio-professional groups of the community share a common conceptual system represented by the lexeme money.

The English conceptual system of money is represented by the following semantic field: coinage, folding money, paper money ,scrip, banknote, cashier's check, check, draft, money order, note, promissory note bill, dollar, greenback, bankroll, capital, finances, funds, roll [slang],

wad, wallet chump change, dime, mite, peanuts, pittance, shoestring, big bucks, boodle, bundle, earth, fortune, king's ransom, megabucks, $\underline{\text { mint }}$,

packet [chiefly British], pot, opulence, treasure, wealth, resources, etc.

The corpus analysis shows that the dominant lexeme money representing the conceptual system in the naïve worldview [16, p.457-479] shows that despite its Latin root it has not become an internationalism and a marker of globalization, see: its corresponding lexemes across languages [17, p.127-8]: Fr.argent, Ital.soldi, Sp. dinero, Prtl. dinheiro, Rum. bani, Ger. Geld, Afr. geld, Dutch geld, Fris. jild, Dan. penge, Sw.pengar, Norw.penger, Chek. penige, Slok. peniage, Slvn. denar, Croat. novac, Lith. penigai,, Let. nauda., Alb. para, Bolg. пари., Ukr. гроші, Rus.деньги, Bel. грошы.

The advances of our internationalism study are attempts to define (1) the role of financial internationalisms and scientific worldview in disintegrating the society into professional and non-professional, (2 the role of the financial naïve worldview in integrating 
professional and non-professional speakers into a unified society, (3) the code switching occurs due to the use of the conceptual systems represented by corresponding semantic fields and (4)internationalisms in the professional discourse secure cross-cultural communication and integrates world community,

CONCLUSION \& PERSPECTIVES. As languages are constantly evolving, the vocabulary is at times fleeting and it can hardly be foreseen whether such items will become obsolete or will survive in the linguistic repertoire of native speakers. Most Internationalisms and Anglicisms are fairly recent acquisitions, dating from the 19th and 20th centuries. Certain European languages like Dutch, German and French have been frequently scrutinized, but little is known about the linguistic influence of English on languages such as Ukrainian, Russian, Bulgarian, Czech, Serb-Croatian, Slovak, Slovenian, and Polish, etc.

The issues of distinguishing between pseudo-Anglicisms and true English coinages will be a new challenge for the author.

\section{References:}

1. Bielenia-Grajewska Magdalena. Linguistic borrowing in the English language of economics. Journal of English Lexicology. 2009. Vol. 3. P.107-126.

2. Chesley P. Lexical borrowings in French: Anglicisms as a separate phenomenon. Journal of French Language Studies. 2010. Vol. 20(3). P.231-251.

3. Cobarrubias Juan. Progress in language planning: International perspectives. Asterdam. Philadelphia: Walter de Gruyter, 1983. 383p.

4. Colson Jean-Pierre. Cross-linguistic phraseological studies: An overview. / Ed. Sylvia Granger, Fanny Meunier. Phraseology: An Interdisciplinary perspective. Amsterdam/Philadelphia: Benjamins, 2008. P. 191-206.

5. Furiassi Cristiano et al.(eds.) The Anglicization of European lexis. Amsterdam/Philadelphia: Benjamins, 2012. 356p.

6. Furiassi Cristiano, Henrik Gottlieb (eds). Pseudo-English: studies on false Anglicisms in Europe. Berlin/Boston/Munich: Walter de Gruyter, 2015. 298p

7. Gardiner S. C. Loan adaptation and the discovery of the genetic relationships of languages. The Slavonic and East European Review. 1983. 61(4). P. 512-517.

8. Geisler Norman. Worlds apart. A Handbook on world views. Eugene, Oregon: Wipf \& Stock Pub, 2003. 308p.

9. Gorlach Manfred. English words abroad. Amsterdam: Benjamins. 2003.189p.

10. Gorlach Manfred. A Dictionary of European Anglicisms: A Usage dictionary of anglicisms in sixteen European languages. Oxford: OUP, 2001.351p.

11. Granger Sylvia, Meunier Fanny. Phraseology: An Interdisciplinary perspective. Amsterdam/Philadelphia: Benjamins, 2008. 422p.

12. Haugen Einar. The analysis of linguistic borrowing. Language. 1950. Vol. 26(2). P. 211-314.

13. Hengst Karlheinz. Terminologisches Minimum pädagogik: russ.-dt., dt.-russ. Berlin: Ministerium für Volksbildung, Hauptabt. Lehrerbildung, 1978. 467-469 S.

14. Hirst Paul, Thompson Grahame. The future of globalization. Journal of the nordic international studies association. 2002. Vol.37 (3). - P.247-265.

15. Loewenthal Marc. The Latin heart of English: English vocabulary practice. Vol.1. London: Liondale Publications, 2008.140p.

16. Mierzwińska-Hajnos Agnieszka. The Linguistic worldview revisited. A cognitive analysis of plant terms. Poznan Studies in Contemporary Linguistics. - 2010. Vol. 46 (4). P. 457-479. $527 \mathrm{p}$.

17. Mykhaylenko Valery V. A Glossary of linguistics and translation studies: English-Ukrainian. Ivano-Frankivsk: IFKDGUL, 2015.

18. Otheguy Ricardo. A. Reconsideration of the notion of loan translation in the analysis of Spanish in the United States./ Ed. Ana Roca and John M. Lipski. Linguistic contact and diversity. Berlin: Mouton de Gruyter, 1993. P .21-43.

19. Piirainen E. Europeanism, internationalism or something else? Proposal for a cross-linguistic and cross-cultural research project on widespread idioms in Europe and beyond. Hermes. 2005. Vol. 35. P. 45-75

20. Pulcini Virginia et al. Lexical influence of English on Indo-European language. / Ed. Cristiano Furiassi et al. The Anglicization of European Lexis. Amsterdam /Philadelphia: Benjamins, 2012. P. 1-26.

21. Schaeffer Francis A. Back to freedom and dignity. The complete works. A Christian worldview. Vol. 1. Westchester, IL: Crossway Books, 1985. P.355-86

22. Solano Ramon Marti. Multi-word loan translations and semantic borrowings in French journalistic discourse. The Anglicization of European lexis. Amsterdam: Benjamins, 2012. P. 199-215.

23. Underhill James. Humboldt, worldview and language. Edinburgh: Edinburgh University Press, 2009. P.176.

24. Weinreich Uriel. Languages in contact: findings and problems. Prague. Paris. New York: Mouton, 1979. (1953). P. 160. 